\title{
Valproic Acid Promotes Human Glioma U87 Cells Apoptosis and Inhibits Glycogen Synthase Kinase-3 $\beta$ Through ERK/Akt Signaling
}

\author{
Chi Zhang ${ }^{a}$ Songlin Liu ${ }^{a}$ Xianrui Yuan ${ }^{a}$ Zhongliang Hu ${ }^{b}$ Haoyu Li $^{a}$ Ming Wu \\ Jian Yuana Zijin Zhao Jun Su ${ }^{a}$ Xiangyu Wang ${ }^{a}$ Yiwei Liao ${ }^{a}$ Qing Liua \\ aDepartment of Neurosurgery, Xiangya Hospital, Central-South University, Changsha, Hunan, ${ }^{b}$ Department \\ of Pathology, Xiangya Hospital, Central-South University, Changsha, Hunan, China
}

\section{Key Words}

Glioma • Valproic acid • Apoptosis • GKS3 $•$ ERK/Akt gene pathway

\begin{abstract}
Background: Valproic acid (VPA), an established antiepileptic drug, was assessed for antitumor activity, including its effects on glioblastoma, but its role has not been determined. Methods: In the present study, we investigated VPA-induced apoptosis effects on human U87 cells by cell viability, lactate dehydrogenase (LDH) release, TUNEL/Hoechst staining and flow cytometric in vitro, then we further explored the underlying molecular mechanisms using the selective antagonists PD98059, LY294002 and SB216763. Results: The data showed that VPA dose-dependent induction of glioma U87 cells to undergo apoptosis through the mitochondria-dependent pathway in vitro. VPA activated the ERK/Akt pathways by increasing their protein phosphorylation and in turn inhibited GKS3 $\beta$ activation by the induction of GKS3 $\beta$ phosphorylation. However, the MAPK inhibitor PD98059 and/or PI3K inhibitor LY294002 were able to antagonize the effects of VPA by abolishing ERK/Akt activations and cancelling GSK3 $\beta$ suppression, thus it impaired VPA apoptosis-inducing effects on glioma cells. Furthermore, the GSK3 $\beta$ inhibitor SB216763 caused a strong suppression of GSK3 $\beta$ activity, which showed similar effects of VPA on regulation of protein expression and apoptosis. Conclusion: These findings suggest that GSK3 $\beta$ may be the central hub for VPA-induced apoptosis and VPA can be further evaluated as a novel agent for glioma therapy.

(C) 2016 The Author(s)

Published by S. Karger AG, Basel
\end{abstract}

\section{Introduction}

Glioma is the most common and deadly primary malignancy in the central nervous system (CNS) [1]. Clinically, glioma, particularly the aggressive form of high-grade glioma 


\section{Cellular Physiology Cell Physiol Biochem 2016;39:2173-2185 \\ \begin{tabular}{l|l|l} 
and Biochemistry & $\begin{array}{l}\text { DOI: 10.1159/000447912 } \\
\text { Published online: November 02, } 2016\end{array}$ & $\begin{array}{l}\text { (c) } 2016 \text { The Author(s). Published by S. Karger AG, Basel } \\
\text { www.karger.com/cpb }\end{array}$ \\
\hline
\end{tabular} \\ Zhang et al.: Valproic Acid Induction of Glioma Cell Apoptosis via GSK-3ß Inhibition}

(glioblastoma, GBM), has an extremely poor prognosis [2]. Over the past few decades, multimodality treatment, using combination of extensive tumor mass resection, radiation therapy, and chemotherapy, has shown little improvement in well being and led median patient survival to only under 15 months $[3,4]$. Even the most frequently used first-line treatment drug, Temozolomide (TMZ) for GBM may only increase an average of two month survival of patients [4]. Thus, it is urgently needed to identify novel strategies to treatment glioma.

Valproic acid (VPA) is a clinically established drug for the treatment of epileptic seizure $[5,6]$ and epileptic seizure could occur in approximately 50\% of GBM patients [7, 8]. One of the mechanisms of VPA antiepileptic activity is known to inhibit activities of histone deacetylase (HDAC) and DNA methyltransferase [9]. Interestingly, increasing evidence suggests that VPA had an anticancer effect in several GBM cell lines [10]. VPA treatment induced cell cycle arrest and enhanced the efficiency of glioma radiotherapy in clinical trials [11]. Also, VPA may show antineoplastic activity based on its gene-regulation functions [1216]. Expression of CD44 and CD56 [17], p21 and topoisomerase-II [18] could be regulated after VPA administration in GBM cell lines. Treatment with VPA in human neuroblastoma cells and human leukemic cell lines resulted in a strong inhibition of cell proliferation and induction of cell differentiation and apoptosis [19-21]. In other human cancer cell lines, administration of VPA inhibited cancer cell growth [22, 23], induced apoptosis-regulatory and differentiation gene expression [24] and decreased angiogenic potency [25].

It was shown that VPA anti-tumor effects may be achieved by stimulating multiple death pathways including both caspase-dependent and -independent apoptotic signaling pathways [21]. However, in GBM, it is still unclear how does VPA initiate the apoptosis process, key signaling pathway (s) and regulation factor (s) are still uncharted. Thus, the present study was designed to assess the effects of VPA on inducing apoptosis using one of the most common human glioma cell lines, U87. Furthermore, we investigated if extracellular signalregulated kinases (ERK), protein kinase B (Akt) and glycogen synthase kinase-3 $\beta$ (GSK3 $\beta$ ) are involved in the mechanism of activity of VPA.

\section{Materials and Methods}

\section{Cell line and culture}

The human glioma U87-MG cell line was obtained from the American Type Culture Collection (Rockville, MD) and cultured in Dulbecco's modified Eagle's medium (DMEM supplemented with 10\% fetal bovine serum (FBS), $100 \mathrm{U}$ penicillin, and $100 \mathrm{U}$ streptomycin (Sigma-Aldrich Chemical Co., St Louis, MO) at $37^{\circ} \mathrm{C}$ in a humidified atmosphere, with $5 \% \mathrm{CO}_{2}$ and $95 \%$ air.

\section{Cell viability assay}

Cells were seeded and grown overnight and treated with 2-16 mM VPA (Sigma-Aldrich Chemical Co., St Louis, MO), $50 \mu \mathrm{M}$ of TMZ (Sigma-Aldrich Chemical Co.), or negative control (solvent only) for up to 72 h. At the end of each experiment, cell viability was assessed using the cell viability assay kit (Promega, Madison, WI), according to the manufacturer's instructions. Briefly, $25 \mu \mathrm{L}$ of treated cell samples were collected to which was added $5 \mu \mathrm{L}$ of cell viability assay reagent per well. The plates were incubated at $37^{\circ} \mathrm{C}$ to allow the cells to convert. Then the fluorescent signal was measured with an automatic microplate reader (BioTek Instruments, Winooski, VT). The data were summarized and expressed as percentage of the control.

Lactate dehydrogenase $(\mathrm{LDH})$ release assay

VPA cytotoxicity was determined by the level of lactate dehydrogenase (LDH), the stable cytosolic enzyme released upon cell lysis. LDH was quantitatively measured with the use of a cytotoxicity assay kit (Promega) according to the manufacturer's instructions. $50 \mu \mathrm{L}$ supernatant of treated cell samples was transferred to a 96-well plate. An equal volume of cytotoxicity assay reagent was added to each well and incubated for $30 \mathrm{~min}$ at $37^{\circ} \mathrm{C}$, and the reaction was stopped by adding stop buffer from the kit. The absorbance rate was measured at $490 \mathrm{~nm}$ using a plate reader (BioTek Instruments). A maximum LDH 


\section{Cellular Physiology Cell Physiol Biochem 2016;39:2173-2185

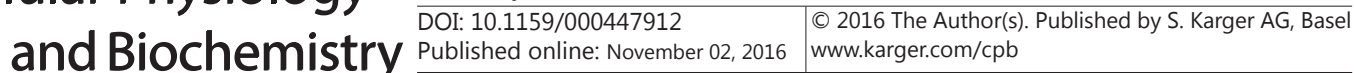 \\ Zhang et al.: Valproic Acid Induction of Glioma Cell Apoptosis via GSK-3ß Inhibition}

release control was set by adding $10 \times$ lysis buffer to lyse all cells $45 \mathrm{~min}$ before the procedure. The data are expressed as a percentage of the maximum LDH release value.

\section{Terminal deoxynucleotidyl transferase dUTP nick end labeling (TUNEL) assay}

The level of VPA-induced apoptosis in glioma cells was assessed using an in situ cell death detection kit (Roche, Mannheim, Germany), according to the manufacturer's instructions. In brief, U87 cells were grown on coverslips and treated with VPA or controls for up to $72 \mathrm{~h}$. The cells were then fixed in freshly made $4 \%$ paraformaldehyde in phosphate-buffered saline (PBS, pH 7.4) with gentle shaking for 60 min at room temperature and rinsed with PBS and treated with $0.1 \%$ Triton X-100 in $0.1 \%$ sodium citrate on ice for 2 min. Next, the cells were incubated with a fluorescein TUNEL-TdT reaction mixture in a humidified chamber at $37^{\circ} \mathrm{C}$ for $60 \mathrm{~min}$ and then reviewed and scored under a Leica fluorescence microscope (Buffalo Grove, IL). The number of TUNEL-positive cells was counted in six different fields. The experiments were repeated six times and the data were summarized as \% of control.

\section{Hoechst staining}

Cell apoptosis was further characterized with Hoechst 33342 (Molecular Probes, USA) staining of nuclear chromatin. Cells were grown on coverslips and treated with VPA or controls for up to $72 \mathrm{~h}$ and then fixed with $4 \%$ formaldehyde for $10 \mathrm{~min}$. After being washed with PBS 3 times, the cells were stained with Hoechst $33342(1 \mu \mathrm{g} / \mathrm{mL}$ in PBS and $0.1 \%$ Triton X-100) for $15 \mathrm{~min}$ at room temperature and intact, fragmented, or condensed DNA was counted under a Leica fluorescence microscope. The experiments were repeated six times. The data are expressed as mean \pm S.E. and reported as $\%$ of control.

\section{Apoptosis flow cytometry assay}

An Annexin V-fluorescein isothiocyanate/propidium iodide (FITC/PI) apoptosis detection kit was obtained from Sigma-Aldrich and used to detect apoptotic cells. Briefly, cells were harvested $72 \mathrm{~h}$ after VPA treatment, centrifuged, washed twice with PBS, and then resuspended in Annexin V-binding buffer. FITCconjugated Annexin V and PI were added to the cells, incubated for $30 \mathrm{~min}$ at room temperature in the dark and analyzed with a flow cytometer (BD Biosciences, Franklin Lakes, NJ). The experiments were repeated at least 3 times and data were summarized as \% of control.

\section{Protein extraction and Western blot}

Total cell lysis was prepared using a lysis buffer (Cell Signaling Technology Inc., Beverly, MA), mitochondria was extracted using a mitochondria isolation kit (Thermo Fisher Scientific Inc., Waltham, MA). The protein concentration was measured using a BCA protein assay kit (Thermo Fisher Scientific Inc.). An equal amount of protein $(60 \mu \mathrm{g} /$ sample $)$ was separated by sodium dodecyl sulfate-polyacrylamide gel electrophoresis (SDS-PAGE) in 10\% SDS-PAGE gels and transferred to polyvinylidene difluoride (PVDF) membranes (Thermo Fisher Scientific Inc.). The membranes were then incubated in 5\% nonfat dry milk in Tris-buffered saline with $0.1 \%$ Triton X-100 (TBST) for $1 \mathrm{~h}$ at room temperature and incubated with primary antibodies dilutions in TBST at $4^{\circ} \mathrm{C}$ overnight. The primary antibodies were anti-ERK1/2 (1:1000), phosphoERK1/2 (1:500), Akt (1:1000), phospho-Akt (1:1000; all from Cell Signaling Technology Inc.), GSK3 $\beta$ (1:500), phospho-GSK3 $\beta$ (pSer ${ }^{9}$ ) (1:500; all from Sigma-Aldrich Chemical Co.), caspase-3 (1:1000), cleavedcaspase-3 (1:500), caspase-9 (1:1000), cleaved-caspase-9 (1:500), Bax (1:500), Bcl-2 (1:500), cytochrome-c (1:500), AIF (1:1000), cleaved-PARP (1:1000), and $\beta$-actin (1:2500; all from Cell Signaling Technology Inc.). After being washed in TBS-T thrice, the membranes were further incubated with a secondary antibody (Cell Signaling Technology Inc.) at room temperature for $1 \mathrm{~h}$. To visualize the protein bands, membranes were briefly incubated with Super Signal West Pico Chemiluminescence Substrate (Thermo Fisher Scientific Inc.) and quantified using Image J software (National Institute of Heath, Bethesda, MD).

\section{Statistical analysis}

All statistical analyses were performed using SPSS 18.0, a statistical software package from SPSS, Inc. (Chicago, IL). The data were presented as mean \pm SD and statistically analyzed using one-way ANOVA followed by the Student-Newman-Keuls test. $\mathrm{P}<0.05$ was considered statistically significant. 


\section{Cellular Physiology

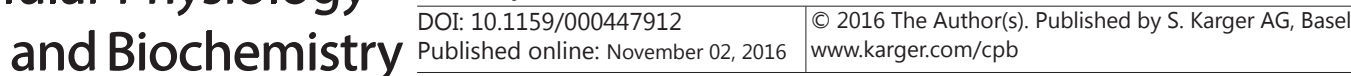 \\ Zhang et al.: Valproic Acid Induction of Glioma Cell Apoptosis via GSK-3 $\beta$ Inhibition}

\section{Results}

VPA dose-dependent induction of glioma U87 cells to undergo apoptosis in vitro

In this study, we first confirmed the effects of VPA on regulation of glioma cell apoptosis in vitro by treating U87 cells with VPA $(2-16 \mathrm{mM})$ or a positive control (TMZ at $50 \mu \mathrm{M})[10$, $26]$. We found that after $72 \mathrm{~h}$ of treatment, VPA markedly reduced tumor cell viability but increased the LDH release in a concentration-dependent manner $(\mathrm{P}<0.05)$ (Fig. 1A and 1B). However, the $72 \mathrm{~h}$ VPA treatment showed significant quantities of obvious TUNEL-positive cells (Fig. 1C and 1E) or Hoechst-positive cells (Fig. 1D and 1F) compared to the control cells $(\mathrm{P}<0.05)$. In addition, compared to $50 \mu \mathrm{M}$ TMZ positive control, $4 \mathrm{mM}$ VPA treatment was able to achieve similar effects of TMZ on cell viability, LDH release, and TUNEL and Hoechst staining.

Flow cytometric Annexin V-FITC/PI data showed no statistical difference among the numbers of necrotic cells in VPA and TMZ treatment groups (data not shown, P > 0.05) (Fig. 2A; Annexin V-FITC-/PI+ cells in Quadrant 1 were necrosis), whereas VPA-treated U87 cells exhibited significantly higher apoptosis in a dose-dependent manner, compared to controls $(\mathrm{P}<0.05)$ (Fig. 2B). Treatment with 4 mM VPA resulted in approximately $25 \%$ of U87 cells

A

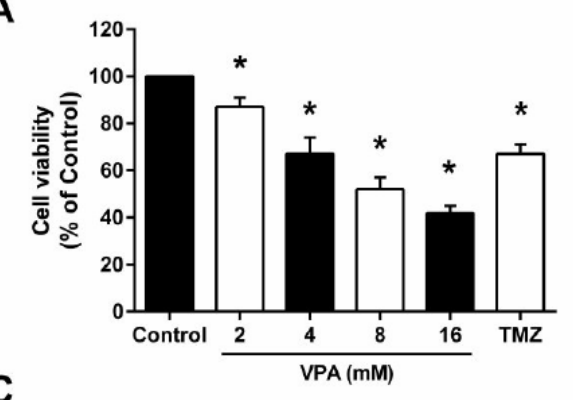

C

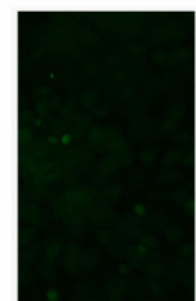

Control

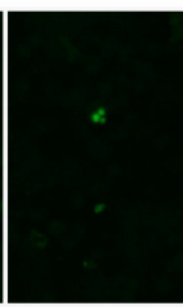

2

D

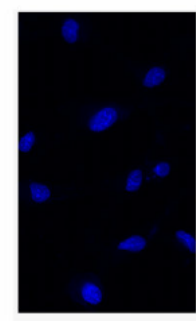

Control
2

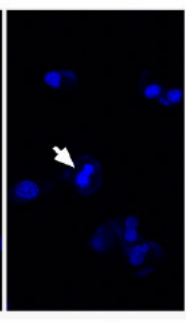

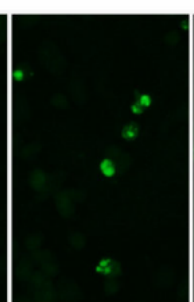

4
B
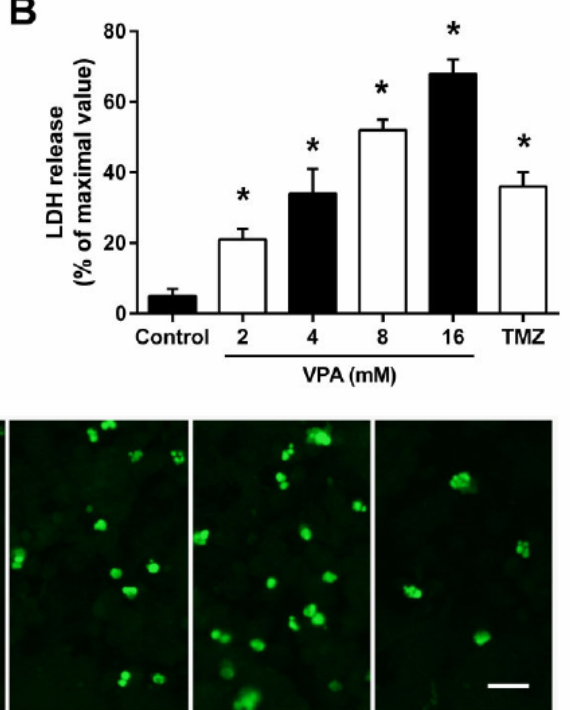

8

VPA (mM)

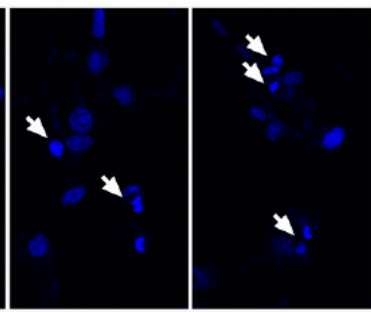

8

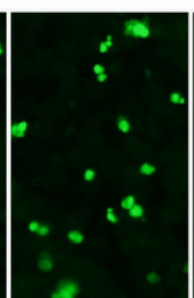

16

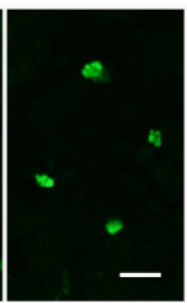

TMZ

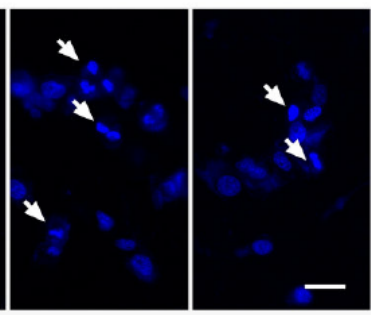

16

TMZ

Fig. 1. Effects of VPA treatment on induction of glioma cell apoptosis. U87 cells were cultured and treated with VPA (2-16 mM) or a positive control TMZ $(50 \mu \mathrm{M})$. After $72 \mathrm{~h}$, cell viability (A) and LDH release assays (B) were measured. TUNEL staining ( $\mathrm{C}$ and $\mathrm{E}$ ) was performed to detect and quantify apoptosis cells. Morphology changes were evident by Hoechst 33342 staining, and the arrow indicates karyopycnosis and nuclear fragmentation (D and F). Scale bar: $25 \mu \mathrm{M}$. The data are presented as means \pm SD of six experiments. ${ }^{*} \mathrm{P}<0.05$ vs. control group. 
Fig. 2. Flow cytometric Annexin V-FITC/propidium iodide (PI) double staining detection of glioma cell apoptosis after VPA treatment. Annexin V-FITC-/PI- (Quadrant 4) cells were alive, and Annexin V-FITC+/PI- cells were considered to be in the early stages of apoptosis (Quadrant 3), while Annexin V-FITC+/ PI+ cells (Quadrant 2) were in the late stages of apoptosis. Annexin V-FITC-/ PI+ cells (Quadrant 1) were necrotic. The total apoptosis rate was calculated as Quadrant 2 + Quadrant 3. The data are presented as means \pm SD of six experiments. $* \mathrm{P}<0.05$ vs. control group.

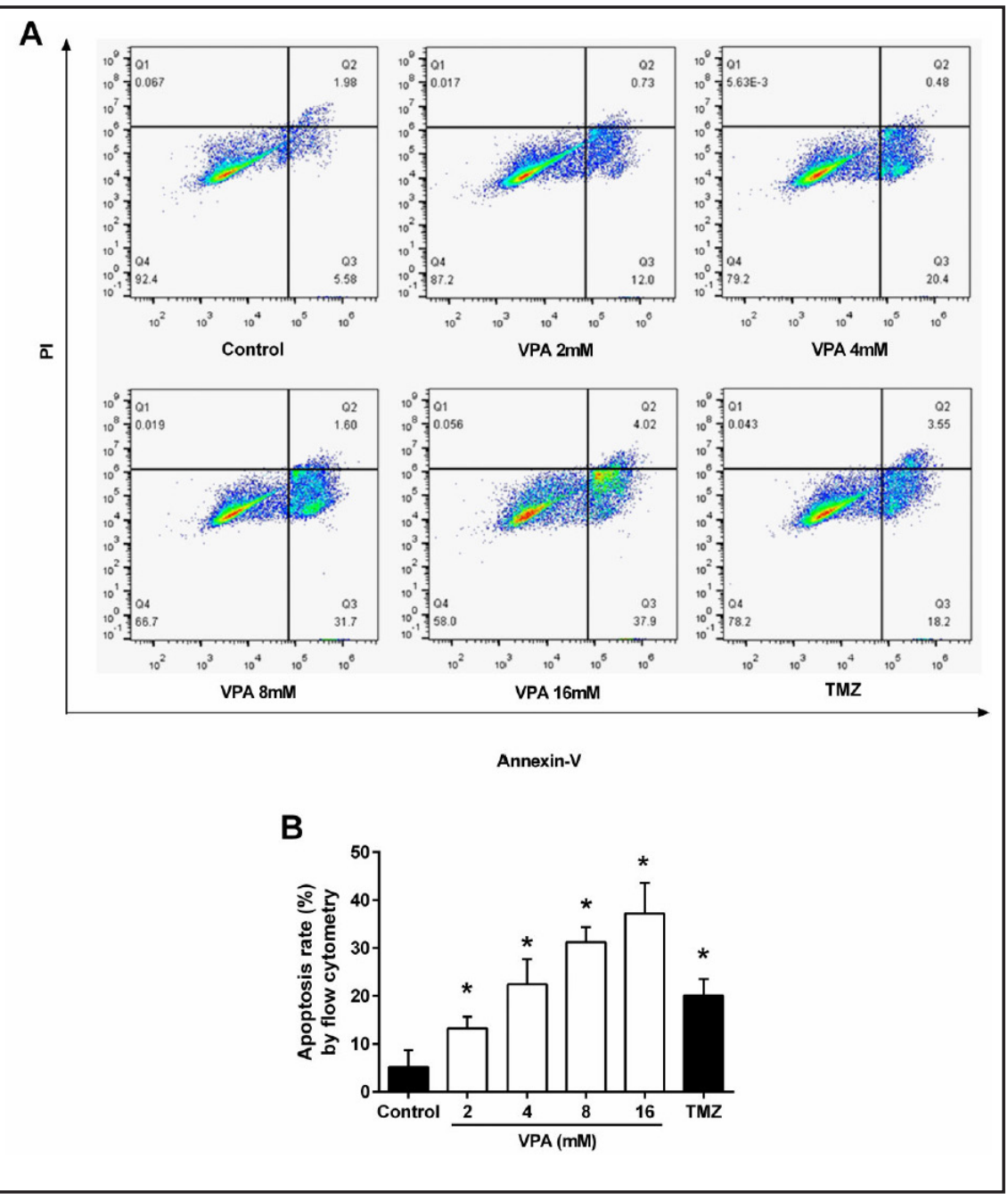

exhibiting apoptosis, a result similar to the TMZ group and identical to the results of TUNEL and Hoechst staining in Figure 1. Thus, we selected this dose for the following in vitro experiments.

\section{VPA activation of ERK and Akt but inhibition of GSK3 $\beta$ in glioma cells}

Then we explored VPA gene regulation in glioma cells and found that multiple signal transduction pathways were involved in VPA-mediated apoptosis in U87 cells (Fig. 3A) and that, after $72 \mathrm{~h}$ of VPA treatment, ERK and Akt proteins were phosphorylated, indicating that their activities were induced (Fig. 3B and 4C) but GSK3 $\beta$ activity was inhibited, because of increased GSK3 $\beta$ phosphorylation (Fig. 3D) (all $P<0.05$ ). To further determine whether GSK3 $\beta$ suppression was due to ERK/Akt activation, simultaneously, we co-treated U87 cells with VPA plus a MAPK inhibitor PD98059 and/or a PI3K inhibitor LY294002 (both at $50 \mu \mathrm{M}$, according to a previous study [27]). After $72 \mathrm{~h}$ of treatment, PD98059 or LY294002 markedly attenuated the level of VPA-induced ERK and Akt phosphorylation and impaired GSK3 $\beta$ phosphorylation (all $\mathrm{P}<0.05$ ). As shown in Figure 3D, treatment with the combination of the two inhibitors completely abolished VPA-induced GSK3 $\beta$ inhibition by phosphorylation $(\mathrm{P}<0.05)$.

Furthermore, direct treatment of U87 cells with a GSK3 $\beta$ inhibitor SB216763 $(20 \mu \mathrm{M}$ according to a previous study [28]) did not impact ERK and Akt activation (Fig. 3B and 3C, all $\mathrm{P}>0.05$ ) but strongly promoted GSK3 $\beta$ phosphorylation (Fig. 3D, $\mathrm{P}<0.05$ ). 


\section{Cellular Physiology Cell Physiol Biochem 2016;39:2173-2185 and Biochemistry \begin{tabular}{l|l} 
DOI: 10.1159/000447912 & (c) 2016 The Author(s). Published by S. Karger AG, Basel \\
\end{tabular}

Fig. 3. Effects of VPA treatment on modulation of protein expression. The data showed multiple signal transduction pathways modified by VPA and inhibitors. Western blot analysis (A). Quantification of Western blot data for p-ERK activity (B), p-Akt activity (C), p-GSK3 $\beta$ activity (D). The data are presented as means \pm SD of six experiments. ${ }^{*} \mathrm{P}<0.05$ vs. control group; ${ }^{\#} \mathrm{P}<0.05$ vs. VPA group. PD, PD98059; LY, LY294002; SB, SB216763.

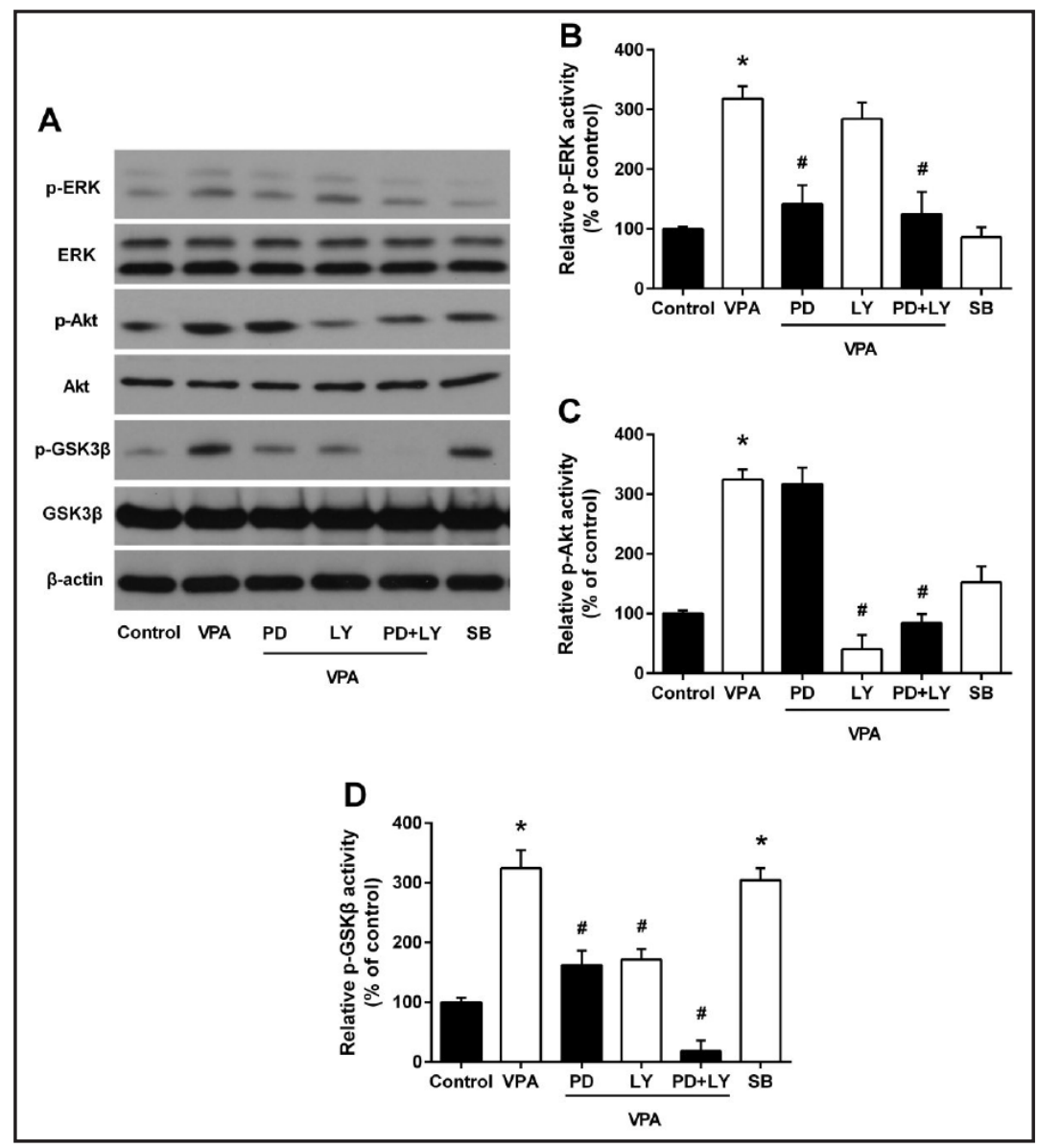

VPA activation of the mitochondria apoptosis in glioma cells in vitro, ERK/Akt pathways and GSK3 $\beta$ contributed to VPA-induced apoptosis

Next, we assessed the mechanism of VPA-induced apoptosis in glioma cells by measured apoptosis-related protein levels (Fig. 4A). We found that VPA induced expression of cleaved caspase 3 and cleaved caspase 9 in U87 cells (Fig. 4B and 4C). Moreover, the expression of Bcl-2 family protein Bax was increased, whereas Bcl-2, the anti-apoptotic member, was decreased by VPA treatment (Fig. 4D and 4E). The release of cytochrome $\mathrm{c}$ from the mitochondria after VPA treatment has also been increased (Fig. 4F and 4G). The expression of apoptosisinducing factor (AIF) and ribose polymerase (PARP) was also up-regulated (Fig. 4H and 4I) (all $\mathrm{P}<0.05$ ). These data suggested that VPA was able to activate the mitochondria-mediated apoptosis pathway.

Further, we assessed the expression of apoptosis-related proteins after the combination of a MAPK inhibitor PD98059, a PI3K inhibitor LY294002, or a GSK3 $\beta$ inhibitor SB216763 with VPA treatment. MAPK inhibitor together with PI3K inhibitor was able to alleviate VPAinduced apoptosis, with a decrease in cleaved caspase-3, cleaved caspase-9, anti-apoptosis protein Bax, cytosol cytochrome c, AIF, cleaved PARP, but with up-regulation of pro-apoptosis protein $\mathrm{Bcl}-2$ and mitochondria cytochrome c (all $\mathrm{P}<0.05$ ). Meanwhile, GSK3 $\beta$ inhibitor was able to regulate expression of apoptosis factors (all $\mathrm{P}<0.05$ ), which has a similar effect to VPA treatment.

Inhibitors of MAPK and PI3K pathways abolished VPA induced apoptosis effects, but GSK3 $\beta$ inhibitor mimicked effects of VPA

MAPK inhibitor PD98059 with PI3K inhibitor LY294002 treatment partially or almost completely neutralized the VPA apoptosis-inducing effects (Fig. 5). However, direct treatment of U87 cells with a GSK3 $\beta$ inhibitor SB216763 $20 \mu \mathrm{M}$ strongly affect tumor cell apoptosis as 
Fig. 4. Effects of VPA on activation of intrinsic mitochondrial apoptosis pathway proteins. Western blot (A). Quantification of Western blot data for cleaved caspase-3 and cleaved capase-9 (B and $\mathrm{C}$ ), anti- and pro-apoptosis protein Bax and Bcl-2 (D and E), mitoCytC (mitochondria cytochrome c) and cyto-CytC (cytosol cytochrome c) (F and $\mathrm{G})$, and AIF and cleaved PARP ( $\mathrm{H}$ and I). The data are presented as means \pm SD of six experiments. ${ }^{*} \mathrm{P}<0.05$ vs. control group; $\quad \mathrm{P}<0.05$ vs. VPA group.

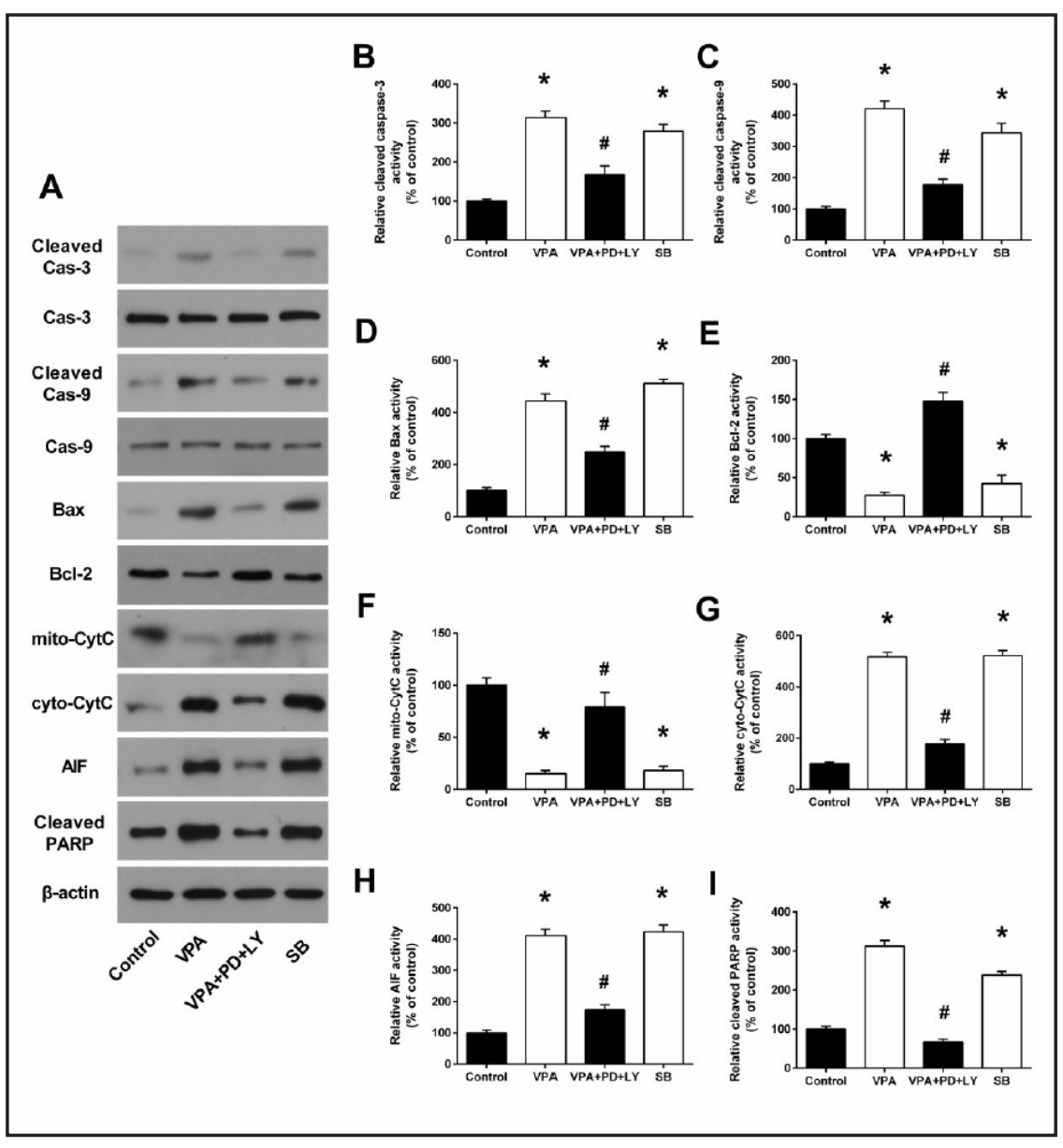

shown in cell viability (Fig. 5A), LDH release (Fig. 5B), TUNEL/ Hoechst staining (Fig. 5C and 5D) and flow cytometry (Fig. 5E) (all P < 0.05).

\section{Discussion}

Apoptosis is an exquisitely programmed and orchestrated cellular process that creates a fragile balance between cell division and cell death to maintain homeostasis in the human body. Apoptosis is also a crucial event in many diseases. For example, increased levels of apoptosis induce degenerative diseases, such as Alzheimer's disease or Parkinson's disease, whereas down-regulated levels of apoptosis can contribute to tumorigenesis [29]. In GBM, apoptosis is inhibited or attenuated by several mechanisms of action, because cell survival promoting molecular chaperones is overexpressed [30-32]. Thus, to effectively control GBM, one possible strategy is to recreate harmony by induction or restoration of the apoptosissignaling pathways to induce GBM cell apoptosis. However, up-to-date management of GBM did not achieve this goal [33]. Radical/extended surgical resection of tumor lesion followed by radiotherapy and concomitant and adjuvant chemotherapy with TMZ is a standard regimen for the treatment of GBM, but did not achieve the desired effects on the control of GBM in a clinical setting [34-36]. TMZ, an alkylating agent that is a first-line treatment option for GBM, has been available in the US for over two decades and shows an ability to induce DNA methylation damage and trigger tumor cell death through autophagy, apoptosis, and necrosis $[37,38]$. Clinically, TMZ showed a certain level of benefits as adjuvant radiotherapy in the improvement of 5-year survival rates of glioma patients [36], but this may not be true of glioma in children [39]. In our current study, we assessed the effects of VPA on glioma 
A

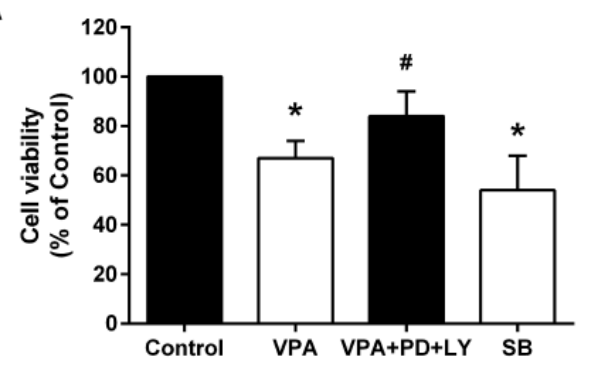

C

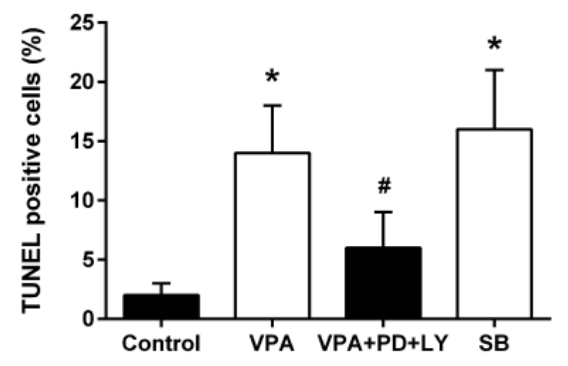

B
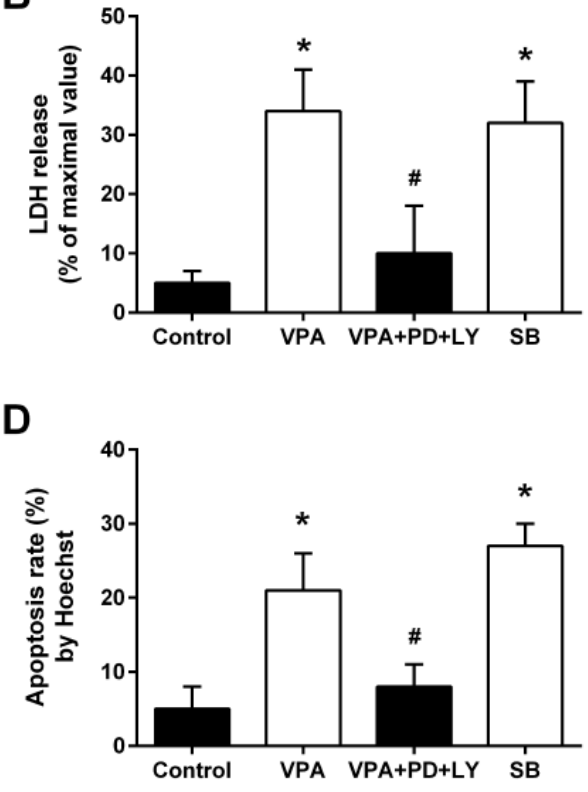

E

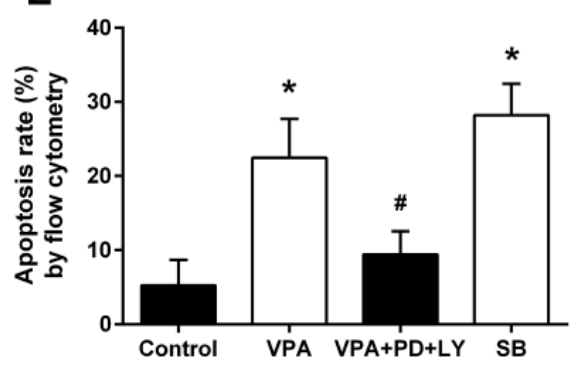

Fig. 5. Modulation of glioma cell apoptosis using different inhibitors with and without VPA. The MAPK inhibitor and PI3K inhibitor together with VPA or GSK3 $\beta$ inhibitor were administered to glioma cells and then subjected to cell viability (A), LDH release (B), TUNEL staining (C), Hoechst staining (D), and flow cytometry (E). ${ }^{*} \mathrm{P}<0.05$ vs. control group; ${ }^{*} \mathrm{P}<0.05$ vs. VPA group.

cells in vitro. VPA is a simple branched-chain fatty acid with a well-established efficacy for seizures. It has been proven to be one of the safest and best-tolerated drugs to date for epilepsy treatment, because VPA can easily and extensively penetrate the blood-brain barrier [40]. Clinically, VPA is widely used to control seizures provoked by brain tumors, including glioma, and surprisingly, it has been shown to have potential radiotherapy benefit in TMZ-resistant malignant glioma [10, 11, 41]. VPA had an anti-cancer effect in U87 at low dosages of the drug, U87 cells may be more sensitive to VPA compared to other GBM lines [10]. Thus, we applied U87 cells models to validate that VPA was able to reduce glioma cell viability and for the first time, we demonstrated that VPA activated ERK/Akt proteins and in turn inhibited GKS3 $\beta$ activity to induce glioma cells to undergo apoptosis.

There are two main apoptosis pathways in cells, i.e., the intrinsic mitochondrial pathway or external cell membrane pathway $[10,11]$. In the mitochondrial apoptosis pathway, the main characteristic is the increased mitochondrial permeability, release of cytochrome c, and pro- apoptotic/anti-apoptotic molecule modification. The balance between pro-apoptotic proteins, like Bax, Bak, and Bad, and anti-apoptotic proteins, including Bcl-2, Bcl-X, and $\mathrm{Bcl}-\mathrm{W}$ are crucial for the regulation of cell survival and death [42]. Through the induction and formation of the apoptosis complex known as apoptosome, these apoptosis factors will 


\section{Cellular Physiology Cell Physiol Biochem 2016;39:2173-2185

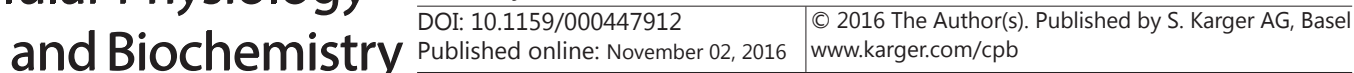

Fig. 6. Illustration of GSK3 $\beta$ as a central apoptosis process for VPA treatment. VPA was able to activate the ERK and Akt pathways, and then lead to GSK3 $\beta$ suppression (phosphorylation) eventually, initiate the mitochondrial apoptosis process. MAPK inhibitor PD98059 and PI3K inhibitor LY294002 were able to antagonize VPA-induced GSK3 $\beta$ suppression and abolish VPA-induced apoptosis in glioma cells. However, GSK3 $\beta$ inhibitor SB216763 was able to directly suppress GSK3 $\beta$ activity and mimic effects of VPA on induction of glioma cell apoptosis.

activate caspase 9 and 3 to degrade genomic DNA and commit cell suicide [32, 43, 44]. We found that VPA treatment of glioma cells in vitro activated the intrinsic mitochondria apoptosis pathway, and blocked expression of pro-survival proteins (Bcl-2 and Bcl-x), but increased expression of the pro-apoptotic protein Bax.

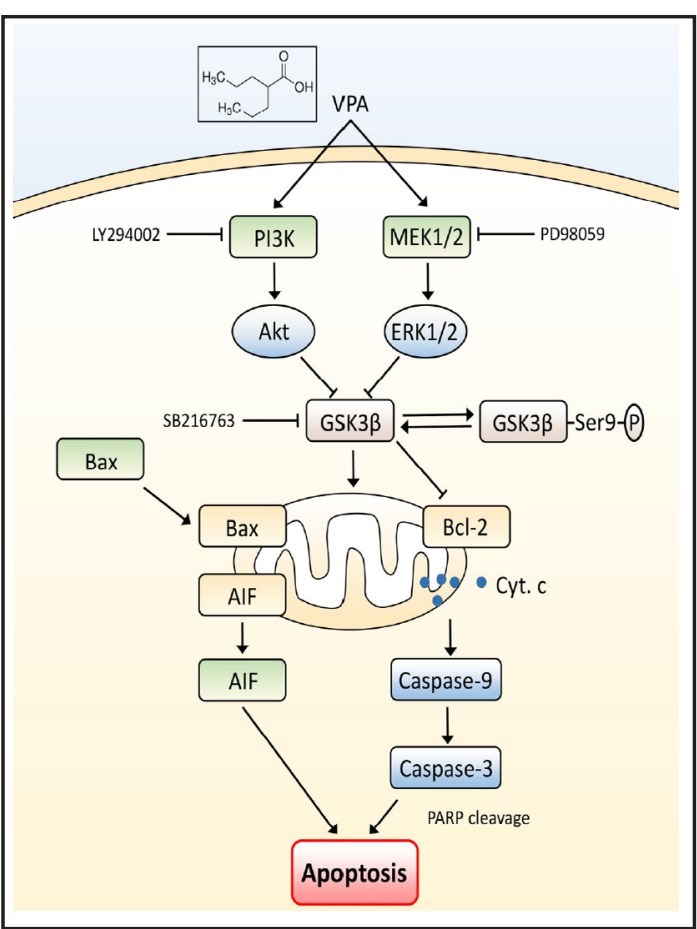

Furthermore, the puzzle is how VPA initiates intrinsic mitochondria apoptosis-related proteins and which signal transduction pathway(s) contribute(s) to this process. Previous studies showed that VPA could activate multiple signal transduction pathways, including HDACs, glycogen synthase kinase 3 (GSK3 $\alpha$ and $\beta$ ), protein kinase B (Akt), extracellular signal-regulated kinases (ERK), $\gamma$-aminobutyric acid, and oxidative phosphorylation [4553]. These pathways can affect critical cellular events, such as cell growth, differentiation, apoptosis, and immunogenicity [54-57]. In our current study, we found that VPA treatment of glioma cells in vitro activated ERK and Akt proteins, but inhibited GSK3 $\beta$ activity. Thus, further investigation of the crosstalk among these cell signal transduction pathways is essential for elucidating the mechanisms of VPA-induced apoptosis. Indeed, the MAPK/ERK pathway is one of the best-studied pathways, which links to very fundamental cell processes, i.e., cell growth, differentiation, migration, and apoptosis [58-61]. Similarly, GSK3 $\beta$ functions in several cell events via self-phosphorylation, and in the brain, it works as a sensor to determine cell fate [62]. The activation of the MAPK pathway by different stimuli may lead to GSK3 $\beta$ inhibition $[58,59,63]$. In addition, as the major target of the PI3K, Akt regulates many downstream targets for the execution of its cell functions (such as cell growth and migration) [64-66]. Previous studies showed that Akt activation led to GSK3 $\beta$ phosphorylation $[67,68]$, while others showed that lithium was able to activate PI3K and Akt and in turn to induce GSK3 $\beta$ phosphorylation and inactivation $[69,70]$. Our current data confirmed that the VPA treatment of glioma cells in vitro activated ERK and Akt proteins but inhibited GSK3 $\beta$ activity. Either MAPK or PI3K inhibitor was able to independently and partly restore GSK3 $\beta$ activity in VPA-treated glioma cells, while the ERK and Akt pathways both contributed to GSK3 $\beta$ suppression. For example, using the MAPK and PI3K inhibitors together, ERK/Akt activation and GSK3 $\beta$ suppression induced by VPA were cancelled. Simultaneously, the apoptosis effect initiated by VPA faded away, and there was no mitochondrial cytochrome c release that occurred in glioma cells, leading to absence of the mitochondria apoptosis pathway activation. Our current data are consistent between GSK3 $\beta$ suppression and apoptosis level, indicating that GSK3 $\beta$ is closely associated with the mitochondria-initialed apoptosis pathway and that it played a central role in mediating VPA-induced apoptosis in glioma cells (Fig. 6).

One of our previous studies showed that VPA markedly up-regulated ERK and Akt activity and protected neurons from trauma-induced brain injury in adult rat cerebral cortex 


\section{Cellular Physiology Cell Physiol Biochem 2016;39:2173-2185

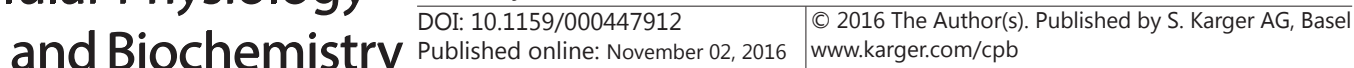 \\ Zhang et al.: Valproic Acid Induction of Glioma Cell Apoptosis via GSK-3ß Inhibition}

[71]. The branch point between VPA-induced protection of normal neurons and VPA-induced glioma cell apoptosis may be the differences in GSK3 $\beta$ expression. In different human cancers, including glioma, GSK3 $\beta$ has been found to consistently express and regulate cell differentiation or growth arrest [72]. Our data demonstrates that either direct inhibition of GSK3 $\beta$, using an inhibitor, or indirect inhibition, using VPA, through activation of the ERK/Akt pathways was able to trigger mitochondria apoptosis activation and induce U87 cells apoptosis. Although GSK3 $\beta$-specific inhibitor SB216763 showed promising apoptosisinducing effects in glioma cells in vitro, the mechanisms have not been fully elucidated. There is still a long way to go to apply it in clinical practice. VPA, which has already been widely used in clinical settings, may be helpful to this dilemma. But, also, further study e.g. xenograft experiments in vivo and clinical testing are indispensable.

\section{Conclusions}

In our current study, we gathered evidence showing that VPA was able to induce apoptosis in glioma cells in a dose-dependent manner through the activation of the mitochondria apoptosis pathway. VPA can induce activation of the ERK and Akt pathways and GSK3 $\beta$ inhibition. Furthermore, modification of GSK3 $\beta$ by the ERK/Akt inhibitor or the GSK3 $\beta$ inhibitor can results in apoptosis. These data suggest that GSK3 $\beta$ may be the central hub for VPA-induced apoptosis and VPA can be further evaluated as a novel agent for glioma therapy. However, our current study is just proof of principle and has limitations, such as the cell line in vitro model. Comprehensive studies including other glioma cell lines or in vivo are still needed.

\section{Acknowledgments}

This work was supported in part by a grant from the The National Key Technology Research and Development Program of the Ministry of Science and Technology of China (2014BAI04B02).

\section{Disclosure Statement}

The authors declare that there is no conflict of interest in this work.

\section{References}

1 Jemal A, Siegel R, Xu J, Ward E: Cancer statistics, 2010. CA Cancer J Clin 2010;60:277-300.

2 Wen PY, Kesari S: Malignant gliomas in adults. N Engl J Med 2008;359:492-507.

3 Cancer Genome Atlas Research N, Brat DJ, Verhaak RG, Aldape KD, Yung WK, Salama SR, Cooper LA, Rheinbay E, Miller CR, Vitucci M, Morozova O, Robertson AG, Noushmehr H, Laird PW, Cherniack AD, Akbani R, Huse JT, et al.: Comprehensive, Integrative Genomic Analysis of Diffuse Lower-Grade Gliomas. N Engl J Med 2015;372:2481-2498.

4 Stupp R, Mason WP, van den Bent MJ, Weller M, Fisher B, Taphoorn MJ, Belanger K, Brandes AA, Marosi C, Bogdahn U, Curschmann J, Janzer RC, Ludwin SK, Gorlia T, Allgeier A, Lacombe D, Cairncross JG, Eisenhauer E, Mirimanoff RO, European Organisation for R, Treatment of Cancer Brain T, Radiotherapy G, National Cancer Institute of Canada Clinical Trials G: Radiotherapy plus concomitant and adjuvant temozolomide for glioblastoma. N Engl J Med 2005;352:987-996.

5 Rosenberg G: The mechanisms of action of valproate in neuropsychiatric disorders: can we see the forest for the trees? Cell Mol Life Sci 2007;64:2090-2103.

6 Bowden CL, Singh V: Valproate in bipolar disorder: 2000 onwards. Acta Psychiatr Scand Suppl 2005;10.1111/j.1600-0447.2005.00522.x13-20.

7 van Breemen MS, Rijsman RM, Taphoorn MJ, Walchenbach R, Zwinkels H, Vecht CJ: Efficacy of anti-epileptic drugs in patients with gliomas and seizures. J Neurol 2009;256:1519-1526. 


\section{Cellular Physiology Cell Physiol Biochem 2016;39:2173-2185 \begin{tabular}{l|l|l} 
and Biochemistry $10.1159 / 000447912$ & (c) 2016 The Author(s). Published by S. Karger AG, Basel \\
www.karger.com/cpb
\end{tabular} \\ Zhang et al.: Valproic Acid Induction of Glioma Cell Apoptosis via GSK-3 $\beta$ Inhibition}

8 Glantz MJ, Cole BF, Forsyth PA, Recht LD, Wen PY, Chamberlain MC, Grossman SA, Cairncross JG: Practice parameter: anticonvulsant prophylaxis in patients with newly diagnosed brain tumors. Report of the Quality Standards Subcommittee of the American Academy of Neurology. Neurology 2000;54:1886-1893.

9 Ghodke-Puranik Y, Thorn CF, Lamba JK, Leeder JS, Song W, Birnbaum AK, Altman RB, Klein TE: Valproic acid pathway: pharmacokinetics and pharmacodynamics. Pharmacogenet Genomics 2013;23:236-241.

10 Ryu CH, Yoon WS, Park KY, Kim SM, Lim JY, Woo JS, Jeong CH, Hou Y, Jeun SS: Valproic acid downregulates the expression of MGMT and sensitizes temozolomide-resistant glioma cells. J Biomed Biotechnol 2012;2012:987495.

11 Thotala D, Karvas RM, Engelbach JA, Garbow JR, Hallahan AN, DeWees TA, Laszlo A, Hallahan DE: Valproic acid enhances the efficacy of radiation therapy by protecting normal hippocampal neurons and sensitizing malignant glioblastoma cells. Oncotarget 2015;6:35004-35022.

12 Bacon CL, O'Driscoll E, Regan CM: Valproic acid suppresses G1 phase-dependent sialylation of a $65 \mathrm{kDa}$ glycoprotein in the C6 glioma cell cycle. Int J Dev Neurosci 1997;15:777-784.

13 Chavez-Blanco A, Perez-Plasencia C, Perez-Cardenas E, Carrasco-Legleu C, Rangel-Lopez E, Segura-Pacheco B, Taja-Chayeb L, Trejo-Becerril C, Gonzalez-Fierro A, Candelaria M, Cabrera G, Duenas-Gonzalez A: Antineoplastic effects of the DNA methylation inhibitor hydralazine and the histone deacetylase inhibitor valproic acid in cancer cell lines. Cancer Cell Int 2006;6:2.

14 Cinatl J, Jr., Cinatl J, Scholz M, Driever PH, Henrich D, Kabickova H, Vogel JU, Doerr HW, Kornhuber B: Antitumor activity of sodium valproate in cultures of human neuroblastoma cells. Anticancer Drugs 1996;7:766-773.

15 Michaelis M, Suhan T, Cinatl J, Driever PH, Cinatl J, Jr.: Valproic acid and interferon-alpha synergistically inhibit neuroblastoma cell growth in vitro and in vivo. Int J Oncol 2004;25:1795-1799.

16 Blaheta RA, Michaelis M, Natsheh I, Hasenberg C, Weich E, Relja B, Jonas D, Doerr HW, Cinatl J, Jr: Valproic acid inhibits adhesion of vincristine- and cisplatin-resistant neuroblastoma tumour cells to endothelium. Br J Cancer 2007;96:1699-1706.

17 Knupfer MM, Hernaiz-Driever P, Poppenborg H, Wolff JE, Cinatl J: Valproic acid inhibits proliferation and changes expression of CD44 and CD56 of malignant glioma cells in vitro. Anticancer Res 1998;18:35853589.

18 Das CM, Aguilera D, Vasquez H, Prasad P, Zhang M, Wolff JE, Gopalakrishnan V: Valproic acid induces p21 and topoisomerase-II (alpha/beta) expression and synergistically enhances etoposide cytotoxicity in human glioblastoma cell lines. J Neurooncol 2007;85:159-170.

19 Rocchi P, Tonelli R, Camerin C, Purgato S, Fronza R, Bianucci F, Guerra F, Pession A, Ferreri AM: p21Waf1/ Cip1 is a common target induced by short-chain fatty acid HDAC inhibitors (valproic acid, tributyrin and sodium butyrate) in neuroblastoma cells. Oncol Rep 2005;13:1139-1144.

20 Rezacova M, Vavrova J, Vokurkova D, Zaskodova D: Effect of valproic acid and antiapoptotic cytokines on differentiation and apoptosis induction of human leukemia cells. Gen Physiol Biophys 2006;25:65-79.

21 Kawagoe R, Kawagoe H, Sano K: Valproic acid induces apoptosis in human leukemia cells by stimulating both caspase-dependent and -independent apoptotic signaling pathways. Leuk Res 2002;26:495-502.

22 Xia Q, Sung J, Chowdhury W, Chen CL, Hoti N, Shabbeer S, Carducci M, Rodriguez R: Chronic administration of valproic acid inhibits prostate cancer cell growth in vitro and in vivo. Cancer Res 2006;66:7237-7244.

23 Angelucci A, Valentini A, Millimaggi D, Gravina GL, Miano R, Dolo V, Vicentini C, Bologna M, Federici G, Bernardini S: Valproic acid induces apoptosis in prostate carcinoma cell lines by activation of multiple death pathways. Anticancer Drugs 2006;17:1141-1150.

24 Shen WT, Wong TS, Chung WY, Wong MG, Kebebew E, Duh QY, Clark OH: Valproic acid inhibits growth, induces apoptosis, and modulates apoptosis-regulatory and differentiation gene expression in human thyroid cancer cells. Surgery 2005;138:979-984; discussion 984-975.

25 Michaelis M, Michaelis UR, Fleming I, Suhan T, Cinatl J, Blaheta RA, Hoffmann K, Kotchetkov R, Busse R, Nau H, Cinatl J, Jr: Valproic acid inhibits angiogenesis in vitro and in vivo. Mol Pharmacol 2004;65:520-527.

26 Roos WP, Batista LF, Naumann SC, Wick W, Weller M, Menck CF, Kaina B: Apoptosis in malignant glioma cells triggered by the temozolomide-induced DNA lesion 06-methylguanine. Oncogene 2007;26:186-197.

27 Chakravarti A, Loeffler JS, Dyson NJ: Insulin-like growth factor receptor I mediates resistance to antiepidermal growth factor receptor therapy in primary human glioblastoma cells through continued activation of phosphoinositide 3-kinase signaling. Cancer Res 2002;62:200-207. 


\section{Cellular Physiology Cell Physiol Biochem 2016;39:2173-2185 \begin{tabular}{l|l|l} 
and Biochemistry & DOI: 10.1159/000447912 & (c) 2016 The Author(s). Published by S. Karger AG, Basel \\
www.karger.com/cpb
\end{tabular} \\ Zhang et al.: Valproic Acid Induction of Glioma Cell Apoptosis via GSK-3 $\beta$ Inhibition}

28 Korur S, Huber RM, Sivasankaran B, Petrich M, Morin P, Jr., Hemmings BA, Merlo A, Lino MM: GSK3beta regulates differentiation and growth arrest in glioblastoma. PLoS One 2009;4:e7443.

29 Wong RS: Apoptosis in cancer: from pathogenesis to treatment. J Exp Clin Cancer Res 2011;30:87.

30 Omuro AM, Faivre S, Raymond E: Lessons learned in the development of targeted therapy for malignant gliomas. Mol Cancer Ther 2007;6:1909-1919.

31 Ohgaki H, Kleihues P: Population-based studies on incidence, survival rates, and genetic alterations in astrocytic and oligodendroglial gliomas. J Neuropathol Exp Neurol 2005;64:479-489.

32 Ghobrial IM, Witzig TE, Adjei AA: Targeting apoptosis pathways in cancer therapy. CA Cancer J Clin 2005;55:178-194.

33 Preusser M, de Ribaupierre S, Wohrer A, Erridge SC, Hegi M, Weller M, Stupp R: Current concepts and management of glioblastoma. Ann Neurol 2011;70:9-21.

34 Sathornsumetee S, Reardon DA, Desjardins A, Quinn JA, Vredenburgh JJ, Rich JN: Molecularly targeted therapy for malignant glioma. Cancer 2007;110:13-24.

35 Furnari FB, Fenton T, Bachoo RM, Mukasa A, Stommel JM, Stegh A, Hahn WC, Ligon KL, Louis DN, Brennan C, Chin L, DePinho RA, Cavenee WK: Malignant astrocytic glioma: genetics, biology, and paths to treatment. Genes Dev 2007;21:2683-2710.

36 Stupp R, Hegi ME, Mason WP, van den Bent MJ, Taphoorn MJ, Janzer RC, Ludwin SK, Allgeier A, Fisher B, Belanger K, Hau P, Brandes AA, Gijtenbeek J, Marosi C, Vecht CJ, Mokhtari K, Wesseling P, Villa S, Eisenhauer E, Gorlia T, Weller M, Lacombe D, Cairncross JG, Mirimanoff RO, European Organisation for R, Treatment of Cancer Brain T, Radiation Oncology G, National Cancer Institute of Canada Clinical Trials G: Effects of radiotherapy with concomitant and adjuvant temozolomide versus radiotherapy alone on survival in glioblastoma in a randomised phase III study: 5-year analysis of the EORTC-NCIC trial. Lancet Oncol 2009;10:459-466.

37 Jakubowicz-Gil J, Langner E, Badziul D, Wertel I, Rzeski W: Apoptosis induction in human glioblastoma multiforme T98G cells upon temozolomide and quercetin treatment. Tumour Biol 2013;34:2367-2378.

38 Kanzawa T, Germano IM, Komata T, Ito H, Kondo Y, Kondo S: Role of autophagy in temozolomide-induced cytotoxicity for malignant glioma cells. Cell Death Differ 2004;11:448-457.

39 Cohen KJ, Pollack IF, Zhou T, Buxton A, Holmes EJ, Burger PC, Brat DJ, Rosenblum MK, Hamilton RL, Lavey RS, Heideman RL: Temozolomide in the treatment of high-grade gliomas in children: a report from the Children's Oncology Group. Neuro Oncol 2011;13:317-323.

40 Hegi ME, Diserens AC, Gorlia T, Hamou MF, de Tribolet N, Weller M, Kros JM, Hainfellner JA, Mason W, Mariani L, Bromberg JE, Hau P, Mirimanoff RO, Cairncross JG, Janzer RC, Stupp R: MGMT gene silencing and benefit from temozolomide in glioblastoma. N Engl J Med 2005;352:997-1003.

41 Kerkhof M, Dielemans JC, van Breemen MS, Zwinkels H, Walchenbach R, Taphoorn MJ, Vecht CJ: Effect of valproic acid on seizure control and on survival in patients with glioblastoma multiforme. Neuro Oncol 2013;15:961-967.

42 Danial NN, Korsmeyer SJ: Cell death: critical control points. Cell 2004;116:205-219.

43 Kroemer G, Galluzzi L, Brenner C: Mitochondrial membrane permeabilization in cell death. Physiol Rev 2007;87:99-163.

44 LaCasse EC, Mahoney DJ, Cheung HH, Plenchette S, Baird S, Korneluk RG: IAP-targeted therapies for cancer. Oncogene 2008;27:6252-6275.

45 Gottlicher M, Minucci S, Zhu P, Kramer OH, Schimpf A, Giavara S, Sleeman JP, Lo Coco F, Nervi C, Pelicci PG, Heinzel T: Valproic acid defines a novel class of HDAC inhibitors inducing differentiation of transformed cells. EMBO J 2001;20:6969-6978.

46 Kramer OH, Zhu P, Ostendorff HP, Golebiewski M, Tiefenbach J, Peters MA, Brill B, Groner B, Bach I, Heinzel T, Gottlicher M: The histone deacetylase inhibitor valproic acid selectively induces proteasomal degradation of HDAC2. EMBO J 2003;22:3411-3420.

47 Chen G, Huang LD, Jiang YM, Manji HK: The mood-stabilizing agent valproate inhibits the activity of glycogen synthase kinase-3. J Neurochem 1999;72:1327-1330.

48 Gould TD, Manji HK: Glycogen synthase kinase-3: a putative molecular target for lithium mimetic drugs. Neuropsychopharmacology 2005;30:1223-1237.

49 Chen J, Ghazawi FM, Bakkar W, Li Q: Valproic acid and butyrate induce apoptosis in human cancer cells through inhibition of gene expression of Akt/protein kinase B. Mol Cancer 2006;5:71. 


\section{Cellular Physiology Cell Physiol Biochem 2016;39:2173-2185

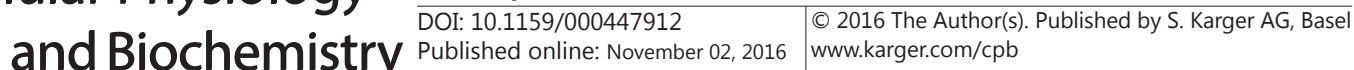 \\ Zhang et al.: Valproic Acid Induction of Glioma Cell Apoptosis via GSK-3ß Inhibition}

50 Michaelis M, Suhan T, Michaelis UR, Beek K, Rothweiler F, Tausch L, Werz O, Eikel D, Zornig M, Nau H, Fleming I, Doerr HW, Cinatl J, Jr.: Valproic acid induces extracellular signal-regulated kinase 1/2 activation and inhibits apoptosis in endothelial cells. Cell Death Differ 2006;13:446-453.

51 Einat H, Yuan P, Gould TD, Li J, Du J, Zhang L, Manji HK, Chen G: The role of the extracellular signalregulated kinase signaling pathway in mood modulation. J Neurosci 2003;23:7311-7316.

52 Phiel CJ, Zhang F, Huang EY, Guenther MG, Lazar MA, Klein PS: Histone deacetylase is a direct target of valproic acid, a potent anticonvulsant, mood stabilizer, and teratogen. J Biol Chem 2001;276:36734-36741.

53 Luis PB, Ruiter JP, Aires CC, Soveral G, de Almeida IT, Duran M, Wanders RJ, Silva MF: Valproic acid metabolites inhibit dihydrolipoyl dehydrogenase activity leading to impaired 2-oxoglutarate-driven oxidative phosphorylation. Biochim Biophys Acta 2007;1767:1126-1133.

54 Li XN, Shu Q, Su JM, Perlaky L, Blaney SM, Lau CC: Valproic acid induces growth arrest, apoptosis, and senescence in medulloblastomas by increasing histone hyperacetylation and regulating expression of p21Cip1, CDK4, and CMYC. Mol Cancer Ther 2005;4:1912-1922.

55 Catalano MG, Fortunati N, Pugliese M, Costantino L, Poli R, Bosco O, Boccuzzi G: Valproic acid induces apoptosis and cell cycle arrest in poorly differentiated thyroid cancer cells. J Clin Endocrinol Metab 2005;90:1383-1389.

56 Tang R, Faussat AM, Majdak P, Perrot JY, Chaoui D, Legrand O, Marie JP: Valproic acid inhibits proliferation and induces apoptosis in acute myeloid leukemia cells expressing P-gp and MRP1. Leukemia 2004;18:1246-1251.

57 Kostrouchova M, Kostrouch Z, Kostrouchova M: Valproic acid, a molecular lead to multiple regulatory pathways. Folia Biol (Praha) 2007;53:37-49.

58 Stambolic V, Woodgett JR: Mitogen inactivation of glycogen synthase kinase-3 beta in intact cells via serine 9 phosphorylation. Biochem J 1994;303:701-704.

59 Shaw M, Cohen P: Role of protein kinase B and the MAP kinase cascade in mediating the EGF-dependent inhibition of glycogen synthase kinase 3 in Swiss 3T3 cells. FEBS Lett 1999;461:120-124.

60 Dunn KL, Espino PS, Drobic B, He S, Davie JR: The Ras-MAPK signal transduction pathway, cancer and chromatin remodeling. Biochem Cell Biol 2005;83:1-14.

61 Yoon S, Seger R: The extracellular signal-regulated kinase: multiple substrates regulate diverse cellular functions. Growth Factors 2006;24:21-44.

62 Cole AR: GSK3 as a Sensor Determining Cell Fate in the Brain. Front Mol Neurosci 2012;5:4.

63 Wang Q, Zhou Y, Wang X, Evers BM: Glycogen synthase kinase-3 is a negative regulator of extracellular signal-regulated kinase. Oncogene 2006;25:43-50.

64 Okumura N, Yoshida H, Kitagishi Y, Murakami M, Nishimura Y, Matsuda S: PI3K/AKT/PTEN Signaling as a Molecular Target in Leukemia Angiogenesis. Adv Hematol 2012;2012:843085.

65 Zhang C, Yuan XR, Li HY, Zhao ZJ, Liao YW, Wang XY, Su J, Sang SS, Liu Q: Anti-cancer effect of metabotropic glutamate receptor 1 inhibition in human glioma U87 cells: involvement of PI3K/Akt/mTOR pathway. Cell Physiol Biochem 2015;35:419-432.

66 Huang W, Wang J, Zhang D, Chen W, Hou L, Wu X, Lu Y: Inhibition of KIF14 Suppresses Tumor Cell Growth and Promotes Apoptosis in Human Glioblastoma. Cell Physiol Biochem 2015;37:1659-1670.

67 David DJ, Wang J, Samuels BA, Rainer Q, David I, Gardier AM, Hen R: Implications of the functional integration of adult-born hippocampal neurons in anxiety-depression disorders. Neuroscientist 2010;16:578-591.

68 Cross DA, Alessi DR, Cohen P, Andjelkovich M, Hemmings BA: Inhibition of glycogen synthase kinase-3 by insulin mediated by protein kinase B. Nature 1995;378:785-789.

69 Young W: Review of lithium effects on brain and blood. Cell Transplant 2009;18:951-975.

70 Muyllaert D, Kremer A, Jaworski T, Borghgraef P, Devijver H, Croes S, Dewachter I, Van Leuven F: Glycogen synthase kinase-3beta, or a link between amyloid and tau pathology? Genes Brain Behav 2008;7:57-66.

71 Zhang C, Zhu J, Zhang J, Li H, Zhao Z, Liao Y, Wang X, Su J, Sang S, Yuan X, Liu Q: Neuroprotective and antiapoptotic effects of valproic acid on adult rat cerebral cortex through ERK and Akt signaling pathway at acute phase of traumatic brain injury. Brain Res 2014;1555:1-9.

72 Luo J: Glycogen synthase kinase 3beta (GSK3beta) in tumorigenesis and cancer chemotherapy. Cancer Lett 2009;273:194-200. 